\title{
BIOLOGICAL INTEGRITY OF STREAMS IN THE REDWATER RIVER TMDL PLANNING AREA (HUC 10060002) BASED ON THE STRUCTURE AND COMPOSITION OF THE BENTHIC ALGAE COMMUNITY
}

Prepared for:

\author{
State of Montana \\ Department of Environmental Quality \\ P.O. Box 200901 \\ Helena, Montana 59620-0901 \\ Project Officer: Rebecca Ridenour \\ DEQ Contract No. 200012-10
}

\author{
Prepared by: \\ Loren L. Bahls, Ph.D. \\ Hannaea \\ 1032 Twelfth Avenue \\ Helena, Montana 59601
}

July 21, 2004 
-

- 


\section{Summary}

In June of 2003, periphyton samples were collected from 8 sites on East Redwater River, Horse Creek, and Pasture Creek for the purpose of assessing whether these streams are waterquality limited and in need of TMDLs. The samples were collected following MDEQ standard operating procedures, processed and analyzed using standard methods for periphyton, and evaluated following modified USEPA rapid bioassessment protocols for wadeable streams.

A large percentage of highly motile diatoms resulted in moderate impairment from sedimentation and partial support of aquatic life uses at sites 04 and 02 on the East Redwater River and at the upper site on Horse Creek. A very large percentage of motile diatoms resulted in severe impairment and nonsupport of aquatic life uses at the lower site on Horse Creek.

A large percentage of pollution tolerant diatoms resulted in moderate impairment from organic loading and partial support of aquatic life uses at the upstream site on the East Redwater River and at both sites on Horse Creek. These sites are also affected by elevated concentrations of dissolved solids (salinity).

Large percentages of Rhoicosphenia abbreviata resulted in depressed diatom species richness, diversity, and equitability values at East Redwater River sites 01 and 03 and, to a lesser extent, at Pasture Creek site 01. R. abbreviata prefers cool, flowing, fresh waters with higher levels of dissolved oxygen. In large numbers, it is more typical of mountain streams than of plains streams. Its abundance in these samples may be the result of higher current velocities at these sites, an influx of fresher (less saline) waters, and the relatively early sampling dates.

Pasture Creek had the best water quality and biological integrity of the three streams. Diatom metrics indicate little or no excess sedimentation and only minor organic loading here. Major diatom species at the upstream site indicate significantly higher salinity levels than the downstream site. The downstream site also supported the largest percentage of Rhopalodiales among samples in the sample set, indicating that nitrogen may be the limiting nutrient here. 


\section{Introduction}

This report evaluates the biological integrity ${ }^{1}$, support of aquatic life uses, and probable causes of stress or impairment to aquatic communities in Horse Creek, Pasture Creek, and the East Redwater River in the Redwater River TMDL planning area of northeastern Montana. The purpose of this report is to provide information that will help the State of Montana determine whether these streams are water-quality limited and in need of TMDLs.

The federal Clean Water Act directs states to develop water pollution control plans (Total Maximum Daily Loads or TMDLs) that set limits on pollution loading to water-quality limited waters. Water-quality limited waters are lakes and stream segments that do not meet waterquality standards, that is, that do not fully support their beneficial uses. The Clean Water Act and USEPA regulations require each state to (1) identify waters that are water-quality limited, (2) prioritize and target waters for TMDLs, and (3) develop TMDL plans to attain and maintain water-quality standards for all water-quality limited waters.

Evaluation of aquatic life use support in this report is based on the species composition and structure of periphyton (benthic algae, phytobenthos) communities at eight sites that were sampled in June of 2003. Periphyton is a diverse assortment of simple photosynthetic organisms called algae that live attached to or in close proximity of the stream bottom. Some algae form long filaments or large colonies that are conspicuous to the unaided eye. But most algae, including the ubiquitous diatoms, can be seen and identified only with the aid of a microscope. The periphyton community is a basic biological component of all aquatic ecosystems. Periphyton accounts for much of the primary production and biological diversity in Montana streams (Bahls et al. 1992). Plafkin et al. (1989) and Barbour et al. (1999) list several advantages of using periphyton in biological assessments.

\footnotetext{
'Biological integrity is defined as "the ability of an aquatic ecosystem to support and maintain a balanced, integrated, adaptive communily of organisms having a species composilion, diversity, and functional organization comparable to that of natural habitats within a region" (Karr and Dudley 1981).
} 


\section{Project Area and Sampling Sites}

The project area is located in Dawson, McCone, and Richland Counties in northeastern Montana. Horse Creek is a west side tributary of the upper Redwater River near Circle (HUC 10060002). Pasture Creek and the East Redwater River are east side tributaries of the Redwater River near the lower end of the drainage.

The streams are located in the Northwestern Great Plains and Northwestern Glaciated Plains Ecoregions (Woods et al. 1999). The surface geology of the area consists of coal-bearing sedimentary rocks of the Fort Union Formation and sandstones and shales of the Montana Group (Renfro and Feray 1972). The climate is semiarid and continental, with cold winters and hot, dry summers. Upland vegetation is predominantly mixed grassland steppe (USDA 1976). The main land uses are livestock grazing and dry land farming.

Periphyton samples were collected at 4 sites on East Redwater River and 2 sites each on Horse Creek and Pasture Creek (Table 1). Elevations at the sample sites range from about 2,500 to 2,000 feet. The streams are classified C-3 in the Montana Surface Water Quality Standards.

\section{Methods}

Periphyton samples were collected following standard operating procedures of the MDEQ Planning, Prevention, and Assistance Division. Using appropriate tools, microalgae were scraped, brushed, or sucked from natural substrates in proportion to the importance of those substrates at each study site. Macroalgae were picked by hand in proportion to their abundance at the site. All collections of microalgae and macroalgae were pooled into a common container and preserved with Lugol's (IKI) solution.

The samples were examined to estimate the relative abundance and rank by biovolume of diatoms and genera of soft (non-diatom) algae according to the method described in Bahls (1993). Soft algae were identified using Smith (1950), Prescott (1962, 1978), John et al. (2002), 
and Wehr and Sheath (2003). These books also served as references on the ecology of the soft algae, along with Palmer $(1969,1977)$.

After the identification of soft algae, the raw periphyton samples were cleaned of organic matter using sulfuric acid, potassium dichromate, and 3\% hydrogen peroxide. Then, permanent diatom slides were prepared using Naphrax ${ }^{\mathrm{TM}}$, a high refractive index mounting medium, following Standard Methods for the Examination of Water and Wastewater (APHA 1998). At least 400 diatom cells ( 800 valves) were counted at random and identified to species. The following were the main taxonomic references for the diatoms: Krammer and Lange-Bertalot 1986, 1988, 1991a, 1991 b; Lange-Bertalot 2001; Krammer 2002. Diatom naming conventions followed the Integrated Taxonomic Information System (http://www.itis.usda.gov). For taxa not yet included in ITIS, naming conventions followed those adopted by the Academy of Natural Sciences for USGS NAWQA samples (Morales and Potapova 2000). Van Dam et al. (1994) was the main ecological reference for the diatoms.

The diatom proportional counts were used to generate an array of diatom association metrics (Table 6). A metric is a characteristic of the biota that changes in some predictable way with increased human influence (Barbour et al. 1999). Diatoms are particularly useful in generating metrics because there is a wealth of information available in the literature regarding the pollution tolerances and water quality preferences of common diatom species (e.g., Lowe 1974, Beaver 1981, Lange-Bertalot 1979, 1996, Van Dam et al. 1994).

Values for selected diatom metrics were compared to biocriteria (numeric thresholds) developed for streams in the Great Plains ecoregions of Montana (Table 2). These criteria are based on the distribution of metric values measured in least-impaired reference streams (Bahls et al. 1992) and metric values measured in streams that are known to be impaired by various sources and causes of pollution (Bahls 1993). The biocriteria in Table 2 are valid only for samples collected during the summer field season (June 21-September 21). (NOTE: The samples analyzed for this report were collected just prior to the summer field season.) 
The criteria in Table 2 distinguish among four levels of stress or impairment and three levels of aquatic life use support: (1) no impairment or only minor impairment (full support); (2) moderate impairment (partial support); and (3) severe impairment (nonsupport). These impairment levels correspond to excellent, good, fair, and poor biological integrity, respectively.

\section{Quality Assurance}

Several steps were taken to assure that the study results are accurate and reproducible. Upon receipt of the samples, station and sample attribute data were recorded in the Montana Diatom Database and the samples were assigned a unique number, e.g., 3023-01. The first part of this number (3023) designates the sampling site (East Redwater River on state land) and the second part (01) designates the number of periphyton samples that that have been collected at this site for which data have been entered into the Montana Diatom Database.

Sample observations and analyses of soft (non-diatom) algae were recorded in a lab notebook along with information on the sample label. A portion of the raw sample was then used to make duplicate diatom slides. The slide used for the diatom proportional count will be deposited in the Montana Diatom Collection at the University of Montana Herbarium (MONTU) in Missoula. The duplicate slide will be retained in Helena at the offices of Hannaea. Diatom proportional counts have been entered into the Montana Diatom Database.

\section{Results and Discussion}

Results are presented in Tables 3,4, and 5, which are located near the end of this report following the references section. Appendix A consists of a series of diatom reports, one for each sample. Each diatom report contains an alphabetical list of diatom species and their percent abundances, and values for 66 different diatom metrics and ecological attributes (Table 6). 


\section{Sample Notes}

Some of the samples in this sample set (RDWEC04, 02, and 01) were septic, black in color, and smelled of rotten eggs $\left(\mathrm{H}_{2} \mathrm{~S}\right)$. Decomposition of soft algae in these samples was not complete, however, allowing for identification of most specimens. Diatoms and blue-green algae (cyanobacteria) were more resistant to decay than green algae, which were the most problematic to identify. The samples from HRSEC01, RDWEC02, and RDWEC04 were silty to extremely silty. Fine particulate organic matter (FPOM) was abundant in the sample collected from RDWEC04. The samples from HRSEC02, RDWEC01, 03, and 04, and both sites on Pasture Creek contained bits and pieces of aquatic macrophytes and/or terrestrial plants.

\section{Non-Diatom Algae (Table 3)}

These streams supported 13 genera of non-diatom algae in 3 algal divisions (Table 3 ). Green algae and cyanobacteria were the most diverse and most abundant groups of non-diatom algae. A filamentous chrysophyte (Tribonema) was present at upstream sites. Each site supported from 1 to 8 genera of non-diatom algae.

Diatoms accounted for most of the biovolume in samples from upper Horse Creek and upper Pasture Creek (Table 3). The filamentous green alga Rhizoclonium was the most abundant alga in all of the other samples. Rhizoclonium has been reported to cause problems in standing and slowly flowing waters across the western United States (Wehr and Sheath 2003). Algae interfere with water uses-e.g., fishing, swimming, boating, and irrigation-only when standing crops are excessive. Mat-forming filamentous algae are normal components of many aquatic ecosystems, including prairie streams, and there is no evidence from this study that standing crops of Rhizoclonium are excessive in these streams. Also, criteria have not been established for determining when algal growth in prairie streams is excessive.

Cyanobacteria, some species of which can fix atmospheric nitrogen, were common in the upper reaches of the East Redwater River and in Horse Creek and Pasture Creek. Nitrogen may 
be the limiting nutrient at these sites. Cyanobacteria were absent from the lower sites on East Redwater River.

The filamentous chrysophyte Tribonema is known to favor cool water temperatures. Tribonema was common in samples collected from RDWEC03 and upper Horse Creek and upper Pasture Creek.

\section{Diatoms (Table 4)}

Of thell major diatom species in the study area, only Rhoicosphenia abbreviata is sensitive to organic pollution (class 3 ). Four of the major species are most tolerant of organic pollution (class 1). These species were most abundant at the upper East Redwater site and in Horse Creek. The remaining 6 major species are somewhat tolerant of organic pollution and these (class 2) species were abundant at all sites except upper Horse Creek (Table 4).

East Redwater River. A large percentage of highly motile diatoms resulted in moderate impairment from sedimentation and partial support of aquatic life uses at sites 04 and 02 . A low pollution index and low species richness also indicated moderate impairment at the upper site (04). The dominant species here were Navicula veneta and Nitzschia aurariae. Both of these species are tolerant of high levels of $\mathrm{BOD}_{5}$ and dissolved solids, hence the most likely causes of impairment at site 04 are excessive sedimentation, organic loading, and salinity.

Extremely low species richness and diversity values indicate severe stress for a prairie stream at site 03 (Table 4). Rhoicosphenia abbreviata accounted for nearly $60 \%$ of the diatom assemblage at this site. This autotrophic, alkaliphilous, periphytic diatom prefers cool, flowing waters, fairly high levels of dissolved oxygen, and large amounts of inorganic nutrients (Van Dam et al. 1994). Although initially believed to be an "oligohalobe" (Patrick and Reimer 1966), Krammer and Lange-Bertalot (1986) report it from "electrolytically rich to brackish inland waters and seacoasts". They also observe it to be a "guter Verschmutzungsindikator" (good pollution indicator) of moderate organic loading. R. abbreviata most likely flourished here because of higher current velocities, cooler waters, and lower concentrations of dissolved solids 
at this site. These are attributes that are more common in mountain streams, where diatom species richness and diversity tend to be lower. In terms of overall water quality, this site was superior to the upstream site (04), with which it shared only $16 \%$ of its diatom assemblage.

Besides moderate impairment from sedimentation, site 02 had a slightly depressed pollution index, indicating minor to moderate impairment from organic loading. The dominant species here (Cyclotella meneghiniana, Navicula recens, Nitzschia frustulum) are only somewhat tolerant of organic pollution and elevated dissolved solids. Though present here, the pollution tolerant species Navicula veneta and Nitzschia aurariae were much less abundant than they were upstream at site 04 . Site 02 shared only about $31 \%$ of its diatom assemblage with the next upstream site (03), which indicates that a moderate change in environmental conditions occurred between the two sites.

The diatom assemblage from the East Redwater River near its mouth (site 01) was very similar to the assemblage at station 03 in that it was dominated by Rhoicosphenia abbreviata (Table 4). Like station 03, this site likely had higher current velocities, cooler waters, and lower concentrations of dissolved solids than other sites. Hence, the moderate stress noted here was probably natural and related to superior water quality (for a prairie stream) rather than to some form of pollution. The diatom assemblages at sites 01 and 03 have much in common with diatom assemblages from mountain streams. Although site 01 shared only about $35 \%$ of its diatom assemblage with the next upstream site (02), it shared $72 \%$ of its diatom assemblage with site 03. The fact that these sites were sampled early in the season, just before the summer sampling season, might also help to explain why they supported unusually high percentages of Rhoicosphenia abbreviata and low species richness and diversity values.

Horse Creek. Diatom metrics indicate moderate organic loading at both sites, moderate sedimentation at the upper site, and severe sedimentation at the lower site (Table 4). (Note: some sedimentation and internal organic loading may be natural in prairie streams.) Diatom species richmess, diversity, and equitability values were low to moderately low at the two sites. The cause of this low diversity is likely a combination of organic loading and excessive salinity. Some of the most common diatom species in Horse Creek (Navicula veneta. Nitzschia aurariae, 
Nitzschia closterium, Nitzschia palea, Nitzschia obtusa) tolerate both elevated concentrations of dissolved solids and heavy organic loading. Nitrogen-fixing diatoms were present but not abundant at the upper site on Horse Creek, indicating that nitrogen may be the limiting nutrient here. The two Horse Creek stations had little in common floristically, indicating that a major change in environmental conditions occurred between them.

Pasture Creek. Pasture Creek had the best water quality and biological integrity of the three streams. Diatom metrics indicate little or no excess sedimentation and only minor organic loading for a prairie stream. Major diatom species at the upstream site, especially Fragilaria famelica and Tabularia fasciculata, indicate significantly higher levels of salinity than at the downstream site, where Rhoicosphenia abbreviata was the dominant species. The latter species indicates higher current velocities and cooler, fresher waters than upstream. The downstream site also supported the largest percentage of Rhopalodiales among samples in this sample set, indicating that nitrogen may be the limiting nutrient here. The two sites on Pasture Creek shared about $43 \%$ of their diatom assemblages, which indicates that only a minor to moderate change in environmental conditions occurred between them.

\section{Modal Categories (Table 5)}

Several ecological attributes were selected from the diatom reports in the appendix and modal categories of these attributes were extracted to characterize water quality tendencies in tributaries of the Redwater River (Table 5).

Most diatoms at several sites were highly motile nitrogen heterotrophs that tolerate elevated levels of organics and prefer brackish, eutrophic, and alkaline waters. These sites have more salinity and more organic loading than the typical prairie stream in eastern Montana. The modal category for some of the attributes and sites was "not classified", which means that the ecological preferences of the diatoms that comprise the largest group have yet to be determined. 
Modal categories at some other sites represent a significant improvement in water quality. For example, most diatoms at East Redwater sites 01 and 03 and both sites on Pasture Creek were "not motile". This is unusual for prairie streams and is due to the large percentages of Rhoicosphenia abbreviata and other non-motile diatoms at these sites. At other sites, the modal category was the more typical "highly motile". At most sites, the modal category for salinity was "brackish" or "brackish-fresh", but it was "fresh" at East Redwater sites 01 and 03 and in lower Pasture Creek (PSTRC01). At the lower site on Horse Creek, the modal category for pH was "circumneutral", whereas it was "alkaliphilous" at most of the remaining sites. Nitrogen autotrophs (not heterotrophs) dominated the samples from lower East Redwater River and lower Pasture Creek, confirming the lower levels of organic loading at these sites. Diatoms at these sites also indicated higher concentrations of dissolved oxygen than the other sites.

\section{References}

APHA. 1998. Standard Methods for the Examination of Water and Wastewater. 20 ${ }^{\text {th }}$ Edition. American Public Health Association, Washington, D.C.

Bahls, L.L. 1979. Benthic diatom diversity as a measure of water quality. Proceedings of the Montana Academy of Sciences 38:1-6.

Bahls, L.L. 1993. Periphyton Bioassessment Methods for Montana Streams (revised). Montana Department of Health and Environmental Sciences, Helena.

Bahls, L.L., Bob Bukantis, and Steve Tralles. 1992. Benchmark Biology of Montana Reference Streams. Montana Department of Health and Environmental Sciences, Helena.

Barbour, M.T., J. Gerritsen, B.D. Snyder, and J.B. Stribling. 1999. Rapid Bioassessment Protocols for Use In Streams and Wadeable Rivers: Periphyton, Benthic Macroinvertebrates and Fish. Second Edition. EPA841-B-99-002. U.S. Environmental Protection Agency, Office of Water, Washington, D.C.

Beaver, Janet. 1981. Apparent Ecological Characteristics of Some Common Freshwater Diatoms. Ontario Ministry of The Environment, Technical Support Section, Don Mills, Ontario.

Johansen, J.R. 1999. Diatoms of Aerial Habitats. Chapter 12 in Stoermer, E.F., and J.P. Smol (eds.), The Diatoms: Applications For the Environmental and Earth Sciences, Cambridge University Press, New York.

John, D.M., B.A. Whitton, and A.J. Brook (eds.). 2002. The Freshwater Algal Flora of the British Isles: An Identification Guide to Freshwater and Terrestrial Algae. Cambridge University

Karr, J.R., and D.R. Dudley. 1981. Ecological perspectives on water quality goals. Environmental Management 5:55-69. 
Krammer, Kurt. 2002. Cymbella. Volume 3 in Diatoms of Europe, Horst Lange-Bertalot, ed. A.R.G. Gantner Verlag K.G., Germany.

Kranmer, K., and H. Lange-Bertalot. 1986. Bacillariophyceae, Part 2, Volume 1: Naviculaceae. In Ettl, H., J Gerloff, H. Heynig, and D. Mollenhauer (eds.), Freshwater Flora of Middle Europe. Gustav Fischer Publisher, New York.

Krammer, K., and H. Lange-Bertalot. 1988. Bacillariophyceae, Part 2, Volume 2: Bacillariaceae, Epithemiaceae, Surirellaceae. In Ettl, H., J. Gerloff, H. Heynig, and D. Mollenhauer (eds.), Freshwater Flora of Middle Europe. Gustav Fischer Publisher, New York.

Krammer, K., and H. Lange-Bertalot. 1991 a. Bacillariophyceac, Part 2, Volume 3: Centrales, Fragilariaceae, Eunotiaceae. In Ettl, H., J. Gerloff, H. Heynig, and D. Mollenhauer (eds.), Freshwater Flora of Middle Europe. Gustav Fischer Publisher, Stuttgart.

Krammer, K., and H. Lange-Bertalot. 1991b. Bacillariophyceae, Part 2, Volume 4: Achnanthaceae, Critical Supplement to Navicula (Lineolatae) and Gomphonema, Complete List of Literature for Volumes 1-4. In Ettl, H., G. Gartner, J. Gerloff, H. Heynig, and D. Mollenhauer (eds.), Freshwater Flora of Middle Europe. Gustav Fischer Publisher, Stuttgart.

Lange-Bertalot, Horst. 1979. Pollution tolerance of diatoms as a criterion for water quality estimation. Nova Hedwigia 64:285-304.

Lange-Bertalot, Horst. 1996. Rote Liste der limnischen Kieselalgen (Bacillariophyceae) Deutschlands. Schr.-R. f. Vegetationskde., H. 28, pp. 633-677. BfN, Bonn-Bad Godesberg.

Lange-Bertalot, Horst. 2001. Navicula sensu stricto: 10 Genera Separated from Navicula sensu lato; Frustulia. Volume 2 in Diatoms of Europe, Horst Lange-Bertalot, ed. A.R.G. Gantner Verlag K.G., Germany.

Lowe, R.L. 1974. Environmental Requirements and Pollution Tolerance of Freshwater Diatoms. EPA-670/4-74-005. U.S. Environmental Protection Agency, National Environmental Research Center, Office of Research and Development, Cincinnati, Ohio.

McFarland, B.H., B.H. Hill, and W.T. Willingham. 1997. Abnormal Fragilaria spp. (Bacillariophyceae) In streams impacted by mine drainage. Journal of Freshwater Ecology 12(1):141-149.

Morales, E.A., and Marina Potapova. 2000. Third NAWQA Workshop on Harmonization of Algal Taxonomy, May 2000. Patrick Center for Environmental Research, The Academy of Natural Sciences, Philadelphia.

Palmer, C.M. 1969. A composite rating of algae tolerating organic pollution. Journal of Phycology 5:78-82.

Palmer, C.M. 1977. Algae and Water Pollution: An Illustrated Manual on the ldentification, Significance, and Control of Algae in Water Supplies and in Polluted Water. EPA-600/9-77-036.

Plafkin, J.L., M.T. Barbour, K.D. Porter, S.K. Gross, and R.M. Hughes. 1989. Rapid Bioassessment Protocols for Use in Rivers and Streams: Benthic Macroinvertebrates and Fish. EPA 440-4-89-001.

Prescott, G.W. 1962. Algae of the Western Great Lakes Area. Wm. C. Brown Company, Dubuque, Iowa.

Prescott, G.W. 1978. How to Know the Freshwater Algae. Third Edition. Wm. C. Brown Company Publishers, Dubuque, lowa.

Renfro, H.B., and D.E. Feray. 1972. Geological Highway Map of the Northern Rocky Mountain Region American Association of Petroleum Geologists, Tulsa, Oklahoma. 
Smith, G.M. 1950. The Fresh-Water Algae of The United States. McGraw-Hill Book Company, New York.

Stevenson, R.J., and Y. Pan. 1999. Assessing Environmental Conditions in Rivers and Streams with Diatoms. Chapter 2 in Stoermer, E.F., and J.P. Smol (eds.), The Diatoms: Applications For the Environmental and Earth Sciences, Cambridge University Press, New York.

Stewart, W.D.P., P. Rowell, and A.N. Rai. 1980. Symbiotic Nitrogen-Fixing Cyanobacteria. Pp. 239-277 in Stewart, W.D.P., and J. Gallo (eds.), Nitrogen Fixation, Academic Press, New York.

USDA. 1976. Climax Vegetation of Montana (map). U.S. Department of Agriculture, Soil Conservation Service, Cartographic Unit, Portland.

USEPA. 2000. Level III Ecoregions of the Continental United States (map). U.S. Environmental Protection Agency, Corvallis, Oregon.

Van Dam, Herman, Adrienne Mertens, and Jos Sinkeldam. 1994. A coded checklist and ecological Indicator values of freshwater diatoms from The Netherlands. Netherlands Journal of Aquatic Ecology 28(1):117-133.

Weber, C.I. (ed.). 1973. Biological Field and Laboratory Methods for Measuring the Quality of Surface Waters and Effluents. EPA-670/4-73-001. U.S. Environmental Protection Agency, National Environmental Research Center, Office of Research and Development, Cincinnati, Ohio.

Wehr, J.D., and R.G. Sheath. 2003. Freshwater Algae of North America: Ecology and Classification. Academic Press, New York.

Whittaker, R.H. 1952. A study of summer foliage insect communities in the Great Smoky Mountains. Ecological Monographs 22:1-44.

Woods, A.J., Omernik, J.M., Nesser, J.A., Shelden, J., and S.H. Azevedo. 1999. Ecoregions of Montana (color poster with map), U.S. Geological Survey, Reston, Virginia. 


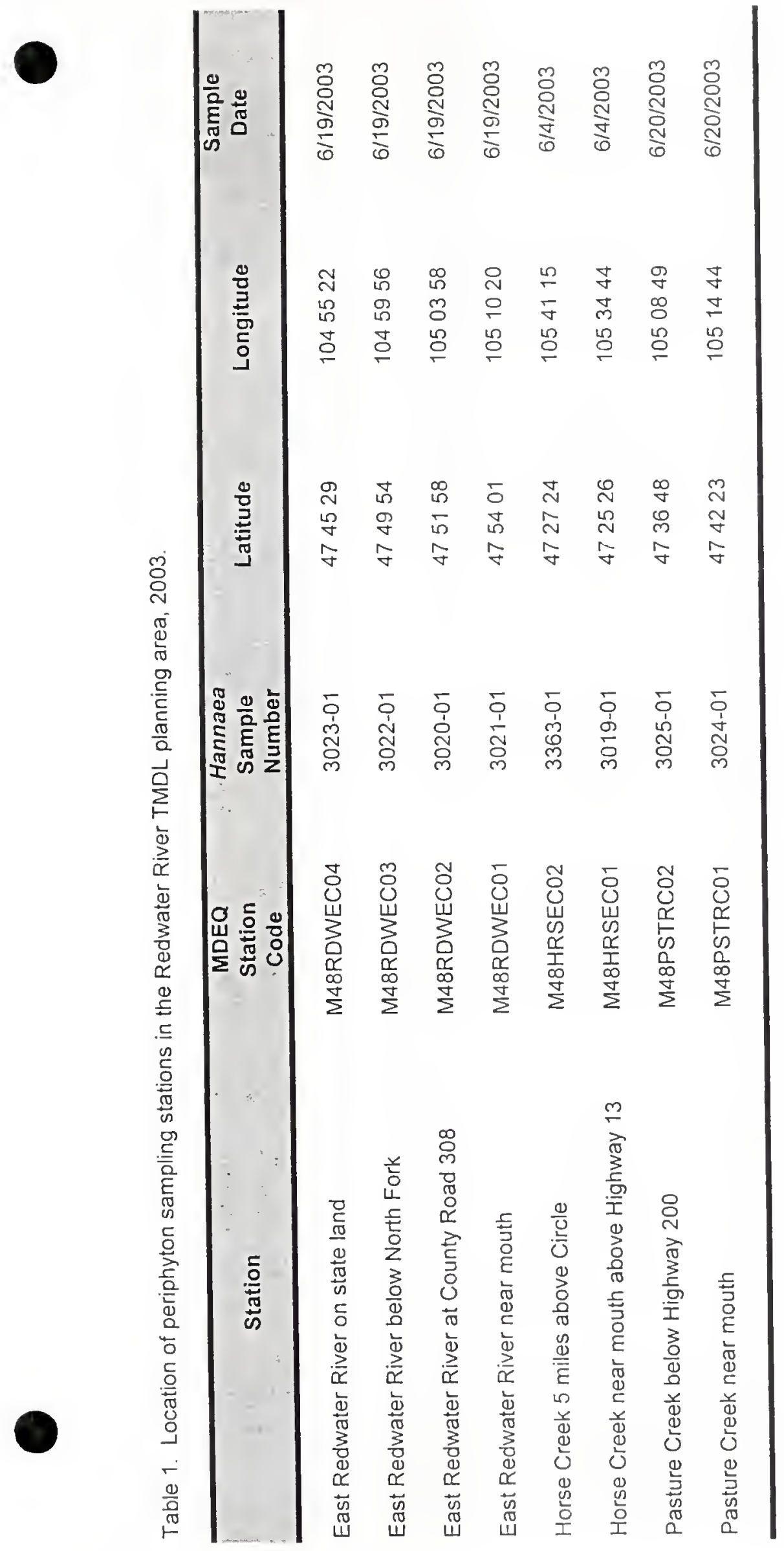




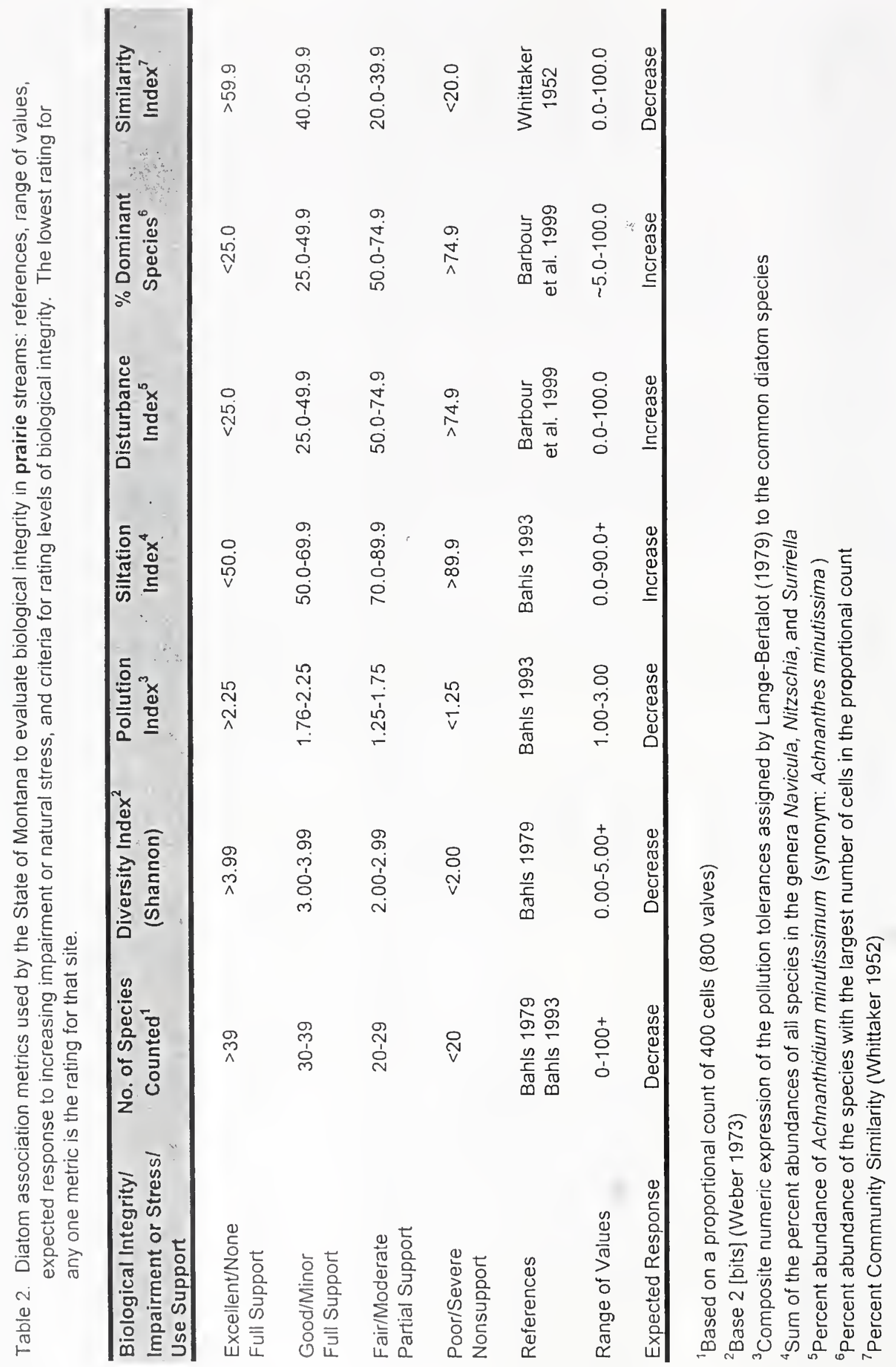




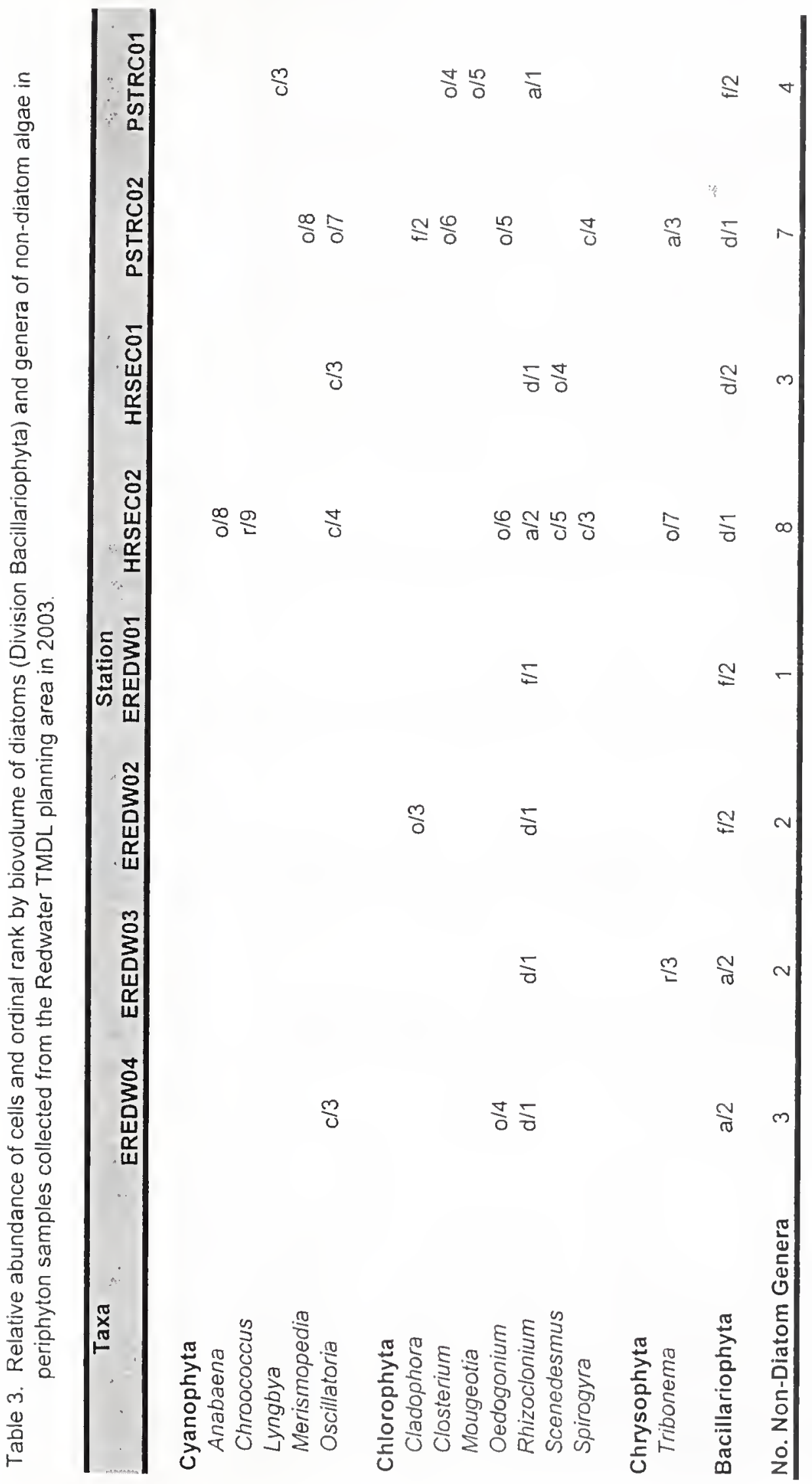




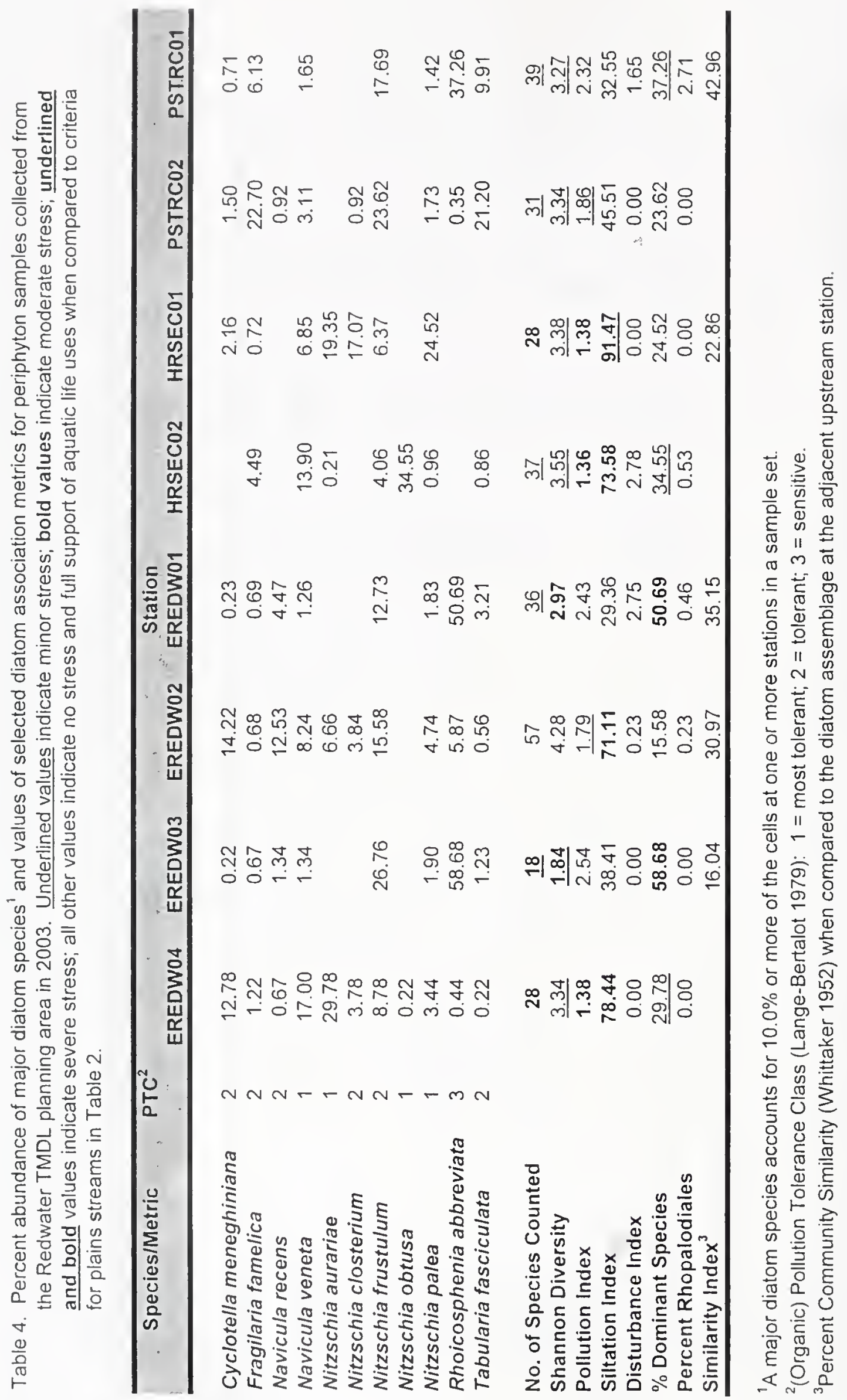




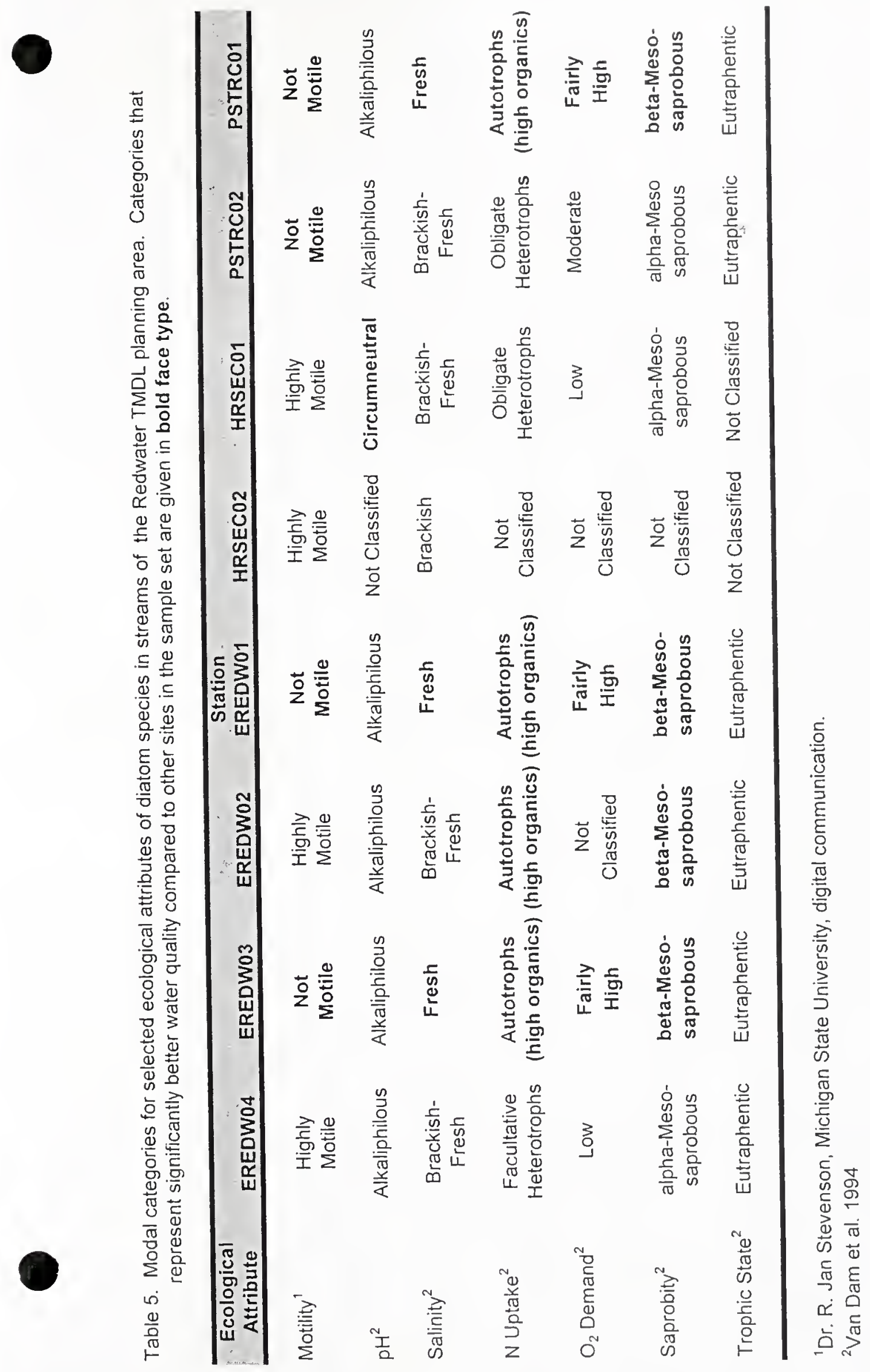




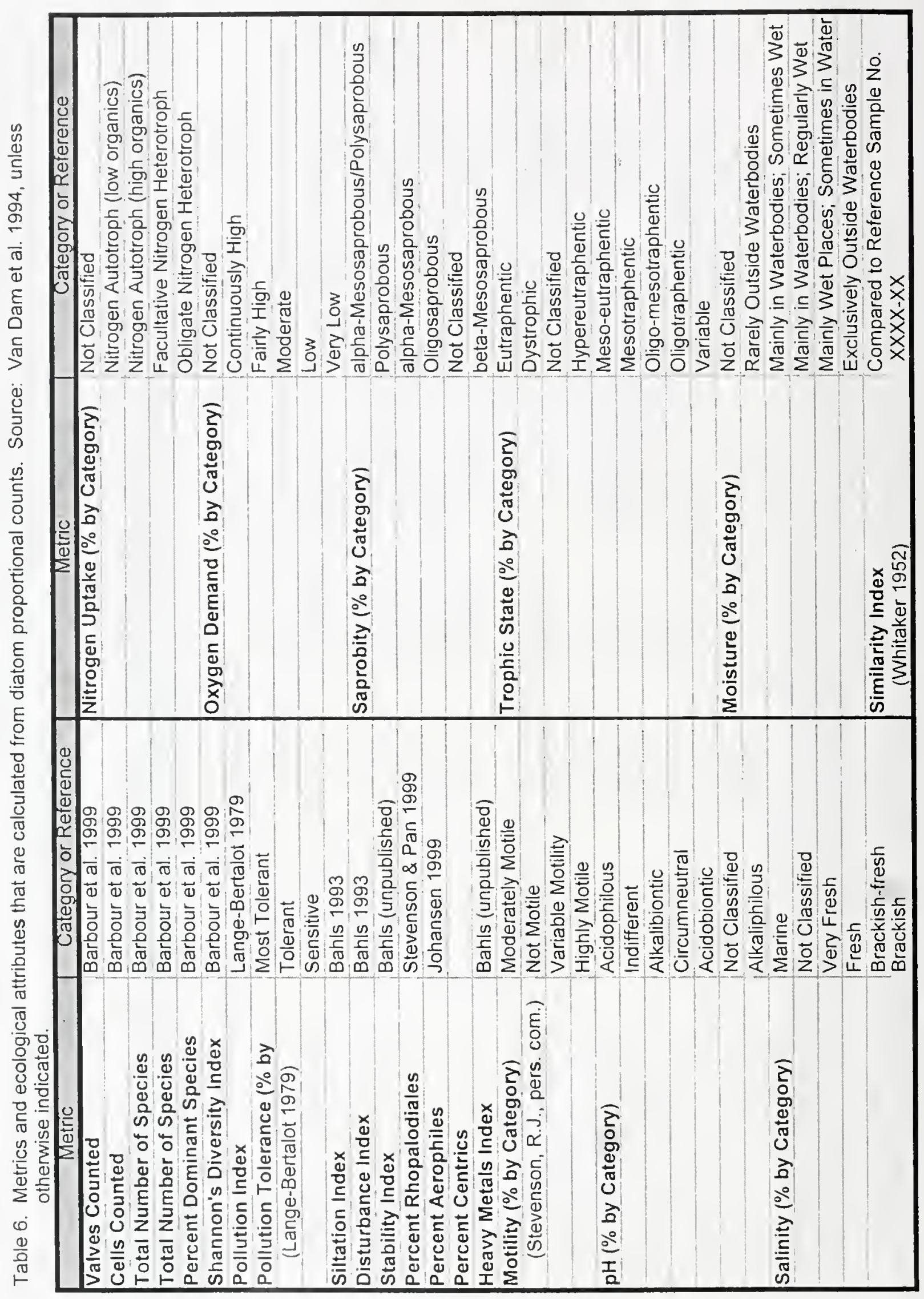

